АДМІНІСТРАТИВНЕ ПРАВО І ПРОЦЕС;
ФІНАНСОВЕ ПРАВО; ІНФОРМАЦІЙНЕ ПРАВО

УДК 342.92:35.08

DOI https://doi.org/10.32844/2618-1258.2019.6.21

\title{
ПРОХОДЖЕННЯ ПУБЛІЧНОЇ СЛУЖБИ 3 ПОЗИЦІї АДМІНІСТРАТИВНОГО СУДОЧИНСТВА
}

АБЛОВ Є.В.

Актуальність теми статті обгрунтовується низьким рівнем інституційного розвитку та престижності державної служби; недосконалістю системи управління персоналом; недосконалістю нормативно-правової бази проходження державної служби; нестабільністю; недостатнім рівнем адміністративної культури державних службовців; недосконалістю системи їх підготовки, спеціалізації та підвищення кваліфікації; низькою якістю та ефективністю результатів їх діяльності. У статті встановлено, що проходження публічної служби з позиції адміністративного судочинства є об'єктом публічно-службового спору, що за своєю суттю включає адміністративні, публічні, професійні правовідносини між фізичною особою (публічним службовцем) та органом державної влади, місцевого самоврядування як суб'єктом призначення, під час яких публічний службовець набуває спеціальну адміністративну правосуб'єктність та стає суб'єктом реалізації владно-управлінських публічних завдань та функцій держави в межах публічно-службових правовідносин. Наголошено, що проходження публічної служби можна визначити з трьох сторін: як соціальна діяльність - це діяльність, що спрямована на виконання делегованих народом владі відповідних завдань та функцій з метою задоволення усіх законних потреб суспільства; як професійно-службова діяльність - це діяльність компетентних та професійних осіб (публічних службовців) в органах державної влади та місцевого самоврядування щодо ефективного виконання владно-управлінських завдань та функцій держави та якісного надання адміністративних послуг у межах адміністративних правовідносин; як адміністративна діяльність - це законодавчо-визначена, ієрархічно-підпорядкована, публічна, службова, владна діяльність публічних службовців щодо виконання владно-управлінських повноважень та надання адміністративних послуг для безпосередньої реалізації державою своїх завдань та функцій. Зроблено висновок, що проходження публічної служби з позиції адміністративного судочинства не включає правовідносини щодо виникнення та припинення публічної служби, а включає саме виконання публічної служби та умови її зміни у публічно-службових правовідносинах.

Ключові слова: адміністративне судочинство, докази, законні інтереси, підсудність, права, предмет, проходження публічної служби, публічна служба, публічний службовещь, публічно-правовий спір, служба, суб'єкт владних повноважень.

The relevance of the topic of the article is justified by the low level of institutional development and prestige of the civil service; imperfection of the personnel management system; imperfection of the legal framework of the civil service; instability; insufficient level of administrative culture of civil servants; imperfection of the system of their preparation, specialization and advanced training; poor quality and efficiency of their perfor-

(C) АБЛОВ С.В. - здобувач наукового ступеня кандидата юридичних наук (Науково-дослідний інститут публічного права) 
mance. The article establishes that the passage of public service from the point of view of administrative justice is the subject of public-service dispute, which in its essence includes administrative, public, professional legal relations between an individual (public servant) and a state authority, local self-government as a subject. appointments, during which a public servant acquires a special administrative legal personality and becomes a subject of realization of public authorities and managerial tasks and functions of the state within the limits of public and official legal relations. It is emphasized that the passage of public service can be defined from three sides: as a social activity - an activity aimed at fulfilling the tasks and functions delegated by the people to the authorities in order to meet all legitimate needs of society; as professional-service activity - is the activity of competent and professional persons (public servants) in public authorities and local self-government in the effective fulfillment of governmental and managerial tasks and functions of the state and high-quality provision of administrative services within the framework of administrative legal relations; as an administrative activity is a legislatively defined, hierarchically-subordinated, public, official, authority activity of public servants in the exercise of power and administrative powers and the provision of administrative services for the direct realization of the state's tasks and functions. It is concluded that the passage of public service from the position of administrative justice does not include legal relations regarding the emergence and termination of public service, but includes the performance of public service and conditions for its change in public service relations.

Key words: administrative proceedings, evidence, legitimate interests, jurisdiction, rights, subject matter, passing public service, public service, public servant, public law dispute, service, subject of authority.

Вступ. Аналіз наявної в Україні системи публічної служби свідчить про те, що вона не відповідає стратегічному курсу держави на демократичний розвиток та впровадження європейських стандартів урядування, оскільки залишається недостатньо професійною, відповідальною, авторитетною, ефективною, є внутрішньо суперечливою та громіздкою, внаслідок чого замість того, щоб бути рушійною силою соціально-економічних і державно-управлінських реформ, гальмує можливість швидких позитивних змін у суспільстві й державі [9, с. 17-18].

Доводиться констатувати, що професіоналізм публічних службовців, їх якісний склад набагато нижчий порівняно з необхідним в умовах адміністративної реформи. Спостерігається низький рівень інституційного розвитку та престижності державної служби; недосконала система управління персоналом (порядок добору кадрів і проведення конкурсів, щорічного оцінювання, оплати праці й мотивації, планування та розвитку кар'єри, визначення потреб у професійному навчанні); недосконалість нормативно-правової бази проходження державної служби; нестабільність; недостатній рівень адміністративної культури державних службовців; недосконалість системи їх підготовки, спеціалізації та підвищення кваліфікації; низька якість та ефективність результатів їх діяльності. Ці системні проблеми в процесі проходження публічної служби в Україні потребують невідкладного вирішення, а демократичні перетворення, що відбуваються в країні, - нових підходів до публічної служби, іiї проходження в умовах адміністративної реформи. Саме тому дослідження проблем та особливостей, визначення основних напрямів вдосконалення проходження публічної служби з позиції адміністративного судочинства в Україні є надзвичайно актуальним $[9$, с. $17-18]$.

Огляд останніх досліджень. Публічна служба була предметом дослідження багатьох науковців, однак адміністративне судочинство у справах, пов'язаних 3 проходженням публічної служби в Україні, удосконалювали та досліджували В. Бевзенко, Н. Берлач, Р. Ботвінов, О. Булгаков, В. Васильківська, В. Галунько, Н. Гладка, О. Губанов, Ю. Дорохіна, М. Іншин, М. Карпа, I. Качур, О. Когут, А. Комзюк, О. Коропатов, О. Корчинський, В. Косик, Л. Кошелева, Р. Куйбіда, В. Поплавський, К. Тимошенко, Н. Хлібороб, М. Цуркан, Н. Янюк та інші. При цьому комплексного дослідження адміністративного судочинства у справах, пов'язаних з проходженням публічної служби в Україні, досі немає, що, відповідно, зумовлює актуальність та своєчасність дослідження цієї наукової площини.

Постановка завдання. Мета статті полягає в тому, щоб на основі комплексного дослідження адміністративно-процесуальних норм, а також позицій вчених-адміністративістів та практики діяльності публічних службовців розкрити проходження публічної служби з позиції адміністративного судочинства. 
Результати дослідження. Що включає в себе поняття «проходження публічної служби»? Передусім необхідно вказати, що зараз немає єдиного законодавчого акту, що забезпечив би регламентування понять, особливостей, видів, принципів, на яких базується публічна служба, понять та видів публічних службовців, способів долучення до публічної служби, основ процесів публічної служби, атестації публічних службовців, головних підстав, щоб припинити публічну службу, відповідальності публічних посадовців, що є основоположними засадами публічної служби. В чинному законодавстві публічна служба є некодифікованою, несистематизованою, а законодавча база з цього питання представлена переважно підзаконними нормативними актами [7, с. 88$]$.

Як встановив О. Дрозд, діяльність державної служби пов'язана з повсякденним рішенням управлінських завдань: збиранням, аналізом і узагальненням інформації, розробкою проектів альтернативних і адекватних рішень, законів, указів, контролем їх виконання, задоволенням потреб населення, що врегульовуються державою, тощо. Отже, проходження державної служби в Україні є беззаперечним складовим елементом предмета адміністративно-правового регулювання [5, с. 101].

В адміністративному праві проходження державної служби розглядається в різних аспектах та під різними кутами зору. Це свідчить про багатогранність та різноманітність цього явища. 3 огляду на те, що державна служба є публічно-правовим інститутом, а державний службовець здійснює публічну діяльність, проходження державної служби, яке походить від самої державної служби та залежить від державного службовця, являє собою процес служіння суспільству та державі шляхом заміщення державної посади та виконання покладених обов'язків. М. Цуркан визначив, що, оскільки проходження державної служби є процесом, який відбувається у певному порядку і напряму, важливо виокремити такі його стадії, враховуючи різноманітні точки зору 3 цього приводу: прийняття на службу, атестація, просування по службі, відповідальність, припинення служби [16, с. 102].

Науковці Б.М. Габрічідзета та А.Г. Чернявський встановили, що проходження державної служби - це процес практичного служіння державі та суспільству особи, призначеної на державну посаду державної служби, виконання відповідного виду управлінської або іншої державно-службової діяльності [4, с. 144]. Л. Коваль визначає інститут проходження держслужби у виконанні управлінських функцій, що досягається через реалізацію компетенції органу виконавчої влади або повноважень якоїсь іншої організації, практична ж реалізація компетенції - це предмет повсякденних турбот особистого складу органів - професійних службовців: державних службовців, менеджерів, розпорядників, власників, уповноважених ними осіб [10, с. 208].

3 позиції проходження служби в правоохоронних органах Х. Босак визначає, що сучасну модель проходження державної служби в органах внутрішніх справ України необхідно розглядати 3 різних поглядів: по-перше, як особливий соціально-правовий інститут реалізації конституційних принципів правової соціальної держави; по-друге, як професію й особливий вид соціальної практики в системі взаємодії працівників поліції з громадянами й державою у формі професійної діяльності щодо безпосереднього здійснення чи забезпечення повноважень державного органу; по-трете, як спеціальний вид соціально та юридично значущої професійної діяльності, яку здійснюють працівники поліції України [2, с. 132].

Науковець О. Коренєв під проходженням державної служби розуміє систему юридичних факторів, що призводять до виникнення, зміни та припинення державно-службових відносин. Це - прийом (зарахування) на державну службу, атестація, переміщення, стимулювання службової діяльності працівників, відповідальність державних службовців, припинення державної служби [12, с. 132].

На думку М. Бурбика, А. Солонар та К. Янішевської, проходження державної служби це сукупність юридичних фактів, пов'язаних із виникненням, зміною та припиненням державно-службових відносин, а саме з прийняттям на державну посаду, службовою кар'єрою та припиненням служби. Цей триваючий постійно процес має стадійний характер [3, с. 145].

Таким чином, на наш погляд, проходження публічної служби можна визначити з трьох сторін: як соціальну діяльність - це діяльність, що спрямована виконання делегованих народом владі відповідних завдань та функцій з метою задоволення усіх законних потреб суспільства; як професійно-службову діяльність - це діяльність компетентних та професійних осіб (публічних службовців) в органах державної влади та місцевого самоврядування щодо ефективного виконання владно-управлінських завдань та функцій держави та якісного надання адміністративних послуг у межах адміністративних правовідносин; як адміністративну діяльність - це законо- 
давчо-визначена, ієрархічно-підпорядкована, публічна, службова, владна діяльність публічних службовців щодо виконання владно-управлінських повноважень та надання адміністративних послуг для безпосередньої реалізації державою своїх завдань та функцій.

Згідно з Кодексом адміністративного судочинства України (далі - КАСУ) юрисдикція адміністративних судів поширюється на справи у публічно-правових спорах, зокрема: спорах з приводу прийняття громадян на публічну службу, ії проходження, звільнення з публічної служби [11].

Тобто законодавець виділяє як вид публічного спору спір з приводу проходження публічної служби.

Відповідно до Класифікатора категорій адміністративних справ, що затверджений Рішенням Ради суддів адміністративних судів України від 31 жовтня 2013 № 114 р., категорія «спори щодо проходження служби» (пункт 12.2 Класифікатора категорій адміністративних справ), серед інших спорів, включає, зокрема, спори щодо: незабезпечення службовця житлом, порушень під час нарахування та здійснення виплат за проходження служби, рішення про застосування до службовця дисциплінарного стягнення, рішення атестаційної комісії за результатами атестації, результатів щорічної оцінки виконання державними службовцями покладених на них обов'язків і завдань [13]. При цьому варто зазначити, що на основі цього Класифікатора визначається спеціалізація суддів (судових палат) адміністративних судів із розгляду справ, розподіляються справи між суддями, ведеться звітність судів про судовий розгляд справ, здійснюється систематизація та узагальнення судової практики, визначаються навантаження на суддів та складність справ, спеціалізація суддів із надання методичної допомоги суддям судів нижчого рівня тощо [13].

До сьогодні сукупність правових норм, яка регулює порядок прийняття на публічну службу, iї проходження та звільнення з публічної служби, визнається: 1) правовим інститутом [8, с. 19]; 2) підгалуззю адміністративного права [1]; 3) комплексною галуззю права [6; 1, с. 15-18].

Очевидно, що подібне різночитання не йде на користь ані науці, ані практиці, оскільки призводить до існування подекуди протилежних та таких, що виключають один одного, підходів до розуміння названого правового утворення. При цьому Т. Аніщенко обстоює ідею надання праву публічної служби статусу підгалузі Особливого адміністративного права. В обгрунтування цього вчена наголошує на такому: по-перше, сучасне адміністративне право наразі розвивається за європейським зразком, що зумовлює його розподіл на два великі блоки: Загальне адміністративне право та Особливе адміністративне право, останнє з яких складається, фактично, із самостійних галузевих утворень. Одним із таких утворень у країнах Європейського Союзу визнається право публічної служби; по-друге, складність і специфічність службово-правових відносин, які виникають за участю публічних службовців з приводу прийняття на публічну службу, її проходження та звільнення з публічної служби, унеможливлює віднесення правових норм, які їх регулюють, до Загального адміністративного права, оскільки учасниками таких відносин $є$ обмежене коло суб'єктів адміністративного права. Відповідно, регулюючий вплив норм права публічної служби поширюється лише на одну групу суб'єктів адміністративного права (публічних службовців), що унеможливлює їх включення до переліку інститутів Загального адміністративного права; по-третє, історичний розвиток права публічної служби також демонструє, що з моменту його виникнення чітко окреслилась тенденція до формування та розвитку останнього як самостійного правового утворення - окремої галузі національного права; по-четверте, не можна не звернути увагу і на певну відокремленість законодавства про публічну службу від решти нормативних актів, які регламентують адміністративно-правові відносини. Наразі маємо певну кількість нормативно-правових актів, які можуть бути застосовані винятково до державних, муніципальних службовців та службовців органів влади Автономної Республіки Крим; по-п’яте, право публічної служби можна розглядати як самостійне підгалузеве утворення, оскільки у його змісті може бути виділено Загальну та Особливу частини; по-шосте, доцільним є виділення права публічної служби в окреме галузеве утворення також і з огляду на потреби його вивчення студентами. У такому разі відповідні правові норми не «загубляться» поміж численних норм адміністративного права, що, безперечно, позитивно позначиться на глибині їх опанування [1, с. 15-18].

Висновки. Таким чином, проходження публічної служби з позиції адміністративного судочинства є об'єктом публічно-службового спору, що за своєю суттю включає адміністративні, публічні, професійні правовідносини між фізичною особою (публічним службовцем) та органом державної влади, місцевого самоврядування як суб'єктом призначення, під час яких публічний службовець набуває спеціальної адміністративної правосуб'єктності та стає суб'єктом реалізації владно-управлінських публічних завдань та функцій держави в межах публічно-службових правовідносин. 
Тобто проходження публічної служби з позиції адміністративного судочинства не включає правовідносини щодо виникнення та припинення публічної служби, а включає саме виконання публічної служби та умови ії зміни у публічно-службових правовідносинах.

\section{Список використаних джерел:}

1. Аніщенко Т. Право публічної служби в системі адміністративного права. Публічна служба і адміністративне судочинство: здобутки і виклики: Збірник матеріалів I Міжнародної науково-практичної конференції (м. Київ, 5-6 липня 2018 року). Київ : ВД «Дакор», 2018. С. 15-18.

2. Босак Х.3. Реформування проходження державної служби в органах внутрішніх справ України: тенденції й основні аспекти. Актуальні проблеми держави і права. 2015. Вип. 75. С. $126-133$.

3. Бурбика М.М., Солонар А.В., Янішевська К.Д. Адміністративне право України : навчальний посібник. Суми : видавничо-виробниче підприємство «Мрія», 2015. 358 с.

4. Габричидзе Б.Н. Служебное право: учеб. для юрид. вузов. Москва : Изд. торг. корпорация «Дашков и К», 2003. 620 с.

5. Дрозд О. Проходження державної служби в Україні як складова предмета адміністративно-правового регулювання. Підприсмництво, господарство і право. 2016. № 10. С. 97-101.

6. Дякина И.А. Служебное право как комплексная отрасль права : автореф. дисс. ... д-ра юрид. наук : 12.00.14. Р н/Д., 2007. 38 с.

7. Качан Я.В. Правове регулювання проходження публічної служби та професійного розвитку публічних службовців. Менеджер. 2019. № 3. С. 77-88.

8. Ківалов С.В. Публічна служба в Україні : підручник. Одеса : Фенікс, 2011. 688 с.

9. Кізілов Ю.Ю. Особливості проходження державної служби в умовах адміністративної реформи : дис. ... канд. наук з держ. управл. : 12.00.03. Дніпро, 2017. 274 с.

10. Коваль Л. Адміністративне право: курс лекцій для студ. юрид. вузів та ф-тів. Київ : Вентурі, 1998. 405 c.

11. Кодекс адміністративного судочинства України від 06.07.2005 р. Відомості Верховної Ради Украӥни. 2005. № 35-36, 37. Ст. 446.

12. Коренев А.П. Административное право России. Ч. 1. Государственное управление и административное право : ученик. Москва : ЩЩит», 2002. 300 с.

13. Про Класифікатор категорій адміністративних справ та Методичні роз'яснення щодо його застосування: Рішення Ради суддів адміністративних судів України від 31.10.2013 № 114. Верховна Рада України: офіційний веб-сайт. 2018. URL: https://zakon.rada.gov.ua/rada/show/ v0114413-13.

14. Про окремі питання юрисдикції адміністративних судів: Постанова Пленуму Вищого адміністративного суду України від 20.05.2013 № 8. Верховна Рада України: офіційний веб-сайт. 2018. URL: https://zakon.rada.gov.ua/laws/show/v0008760-13/card2\#Card.

15. Про розв'язання спорів, що виникають з відносин публічної служби: інформаційний лист Вищого адміністративного суду України від 26.05.2010 № 753/11/13-10. Верховна Рада України: офіційний веб-сайт. 2018. URL: https://zakon.rada.gov.ua/laws/show/v753_760-10.

16. Цуркан М.I. Щодо визначення поняття та змісту проходження державної служби. Право і Безпека. 2008. Т. 7, № 2. С. 98-102. 